\title{
Yönetimde Duygusal Zekâ ve İşyeri Mutluluğu İlişkisi: Okul Yöneticileri Örneği*
}

\author{
Saffet KARAYAMAN**
}

Öz

Bu çalışmanın amacı, okul yöneticilerinin duygusal zekâ düzeyleri ile onların ișyeri mutlulukları arasında anlamlı bir ilişkinin olup olmadığını ortaya çıkarmaktır. Okul yöneticisi olarak, okul müdür ve müdür yardımcıları ele alınmış ve İstanbul ili Avrupa yakası okulları evreninde anket uygulanmıștır. Anket, kișisel bilgiler formu, duygusal zekâ ölçeği ve ișyeri mutluluğu olmak üzere üç kısımdan oluşmaktadır. Uygulanan ankete 404 okul yöneticisi katılmıș ve elde edilen veriler SPSS programı yardımı ile analiz edilmiștir. Yapılan analizlere göre, Okul yöneticilerini duygusal zekâ düzeyleri arttıkça, işyeri mutluluklarının da arttığı, yine tam tersi olarak duygusal zekâ düzeyleri düștükçe işyeri mutluluk düzeylerinin de düştügü görülmüştür. Kendi duygularının veya başkalarının duygularının farkında olan, duygularını daha verimli kullanabilen, duygularını kontrol edip düzenleyebilen okul yöneticisinin işyeri mutluluğunun da artacağı beklenen bir sonuçtur. Yöneticilerin duygusal zekâ yeteneklerinin geliştirilmesi hem kendi işyeri mutluluklarına hem de tüm işyeri paydaşlarının işyeri mutluluklarına katkı sağlayacağı düşünülmektedir.

Anahtar Kelimeler: Yönetim, Okul Yöneticisi, Eğitim Yönetimi, Duygusal Zekâ, İşyeri Mutluluğu

\section{Relationship between Emotional Intelligence and Workplace Happiness in Management: School Administrators Example}

\begin{abstract}
The aim of this study is to determine whether there is a significant relationship between the emotional intelligence levels of school administrators and their workplace happiness. As a school administrator, school principals and assistant principals were discussed and a questionnaire was applied in the European side of Istanbul. The questionnaire consists of three parts: personal information form, emotional intelligence scale and workplace happiness. 404 school administrators participated in the survey and the data obtained were analyzed with the help of SPSS program. According to the analyzes,

\footnotetext{
Özgün Araştırma Makalesi (Original Research Article)

Geliş/Received: 16.08 .2019

Kabul/Accepted: 12.11 .2020

DOI: http://dx.doi.org/10.17336/igusbd.609054

* Bu çalıșma, İstanbul Gelișim Üniversitesi, Sosyal Bilimler Enstitüsü, İșletme Anabilim Dalı’nda
} 2019 yılında kabul edilen, Prof. Dr. Aydın BAȘBUĞ danıșmanlığında yürütülen “Yönetimde Duygusal Zekâ, İşyeri Mutluluğu ve Etik Karar İlişsisi: Okul Yöneticileri Üzerinde Bir Araștırma” isimli doktora tezinden türetilmiştir.

** Dr., Okul Müdürü, İstanbul İl Milli Eğitim Müdürlüğü, E-posta; saffetkarayaman@gmail.com ORCID https://orcid.org/0000-0001-5624-4678
\end{abstract}


it was seen that as the emotional intelligence levels of school administrators increased, workplace happiness increased, and vice versa, as the emotional intelligence levels decreased, workplace happiness levels decreased. It is expected that the workplace happiness of the school administrator who is aware of his / her own feelings or the feelings of others, can use his / her emotions more efficiently and control and regulate his / her emotions will also increase.

Keywords: Manager, School Management, Educational Management, Emotional Intelligence, Workplace Happiness

\section{Giriş}

En önemli yönetim meselesi, insanın kendini yönetmesi meselesidir. Kişiler arası ilişkilerden, toplumsal ilişkilere, aile bireylerinin kendi aralarındaki ilişkilerinden iş yaşamındaki ilișkilere kadar, duyguları anlayabilme, onları kontrol edip yönetebilme, empati gibi kavramlar her geçen gün önemini daha da arttırmaktadır. Duygusal zekâ yeteneği düşük kişilerin, aile yaşamlarından işyeri hayatlarına, toplumsal ilişsilerinden fiziksel sağlık durumlarına kadar pek çok alanda sorunlarla karşılaşma olasılığının diğerlerine göre daha yüksek olduğu söylenebilir. Duygusal zekâ kavramının; bireylerin hem kişisel hayatlarında hem de iş yaşamlarında kendilerini iyi ya da kötü hissettiren dinamikleri bilmelerini ve hayatlarını ona göre kurgulayabilmelerini ifade ettiği söylenebilir. Bu nedenle, kişinin hem özel hem de çalışma hayatında mutlu olabilmesini etkileyen en önemli değişkenlerden birinin, onun duygusal zekâsıdır diyebiliriz. Özellikle işyeri mutluluğunu oluşturan iş tatmini, iş şevki, işe kenetlenme, ișe adanma, örgütsel bağlılık gibi boyutları etkileyen en önemli faktörlerden biri kuşkusuz kişinin duygularını anlaması, diğer çalışanların duygularını anlaması, duygularını kontrol ve onları yönetebilme gücüdür.

Toplumların geleceğini şekillendiren en önemli unsurun eğitim olduğu bir gerçektir. Bu denli önemli bir kavram olan eğitim sürecinin yöneticisi aynı derecede önemlidir. Okul yöneticisinin duygusal zekâsı ve onun çalıştığı işyerinden mutluluk duyması, eğitim faaliyetlerinin amacına ulaşmasında doğrudan etkili olacaktır. Okul yöneticisinin duygusal zekâ düzeyi ile işyeri mutluluğu seviyesi arasında bir ilişkinin olduğu düşünülmektedir. Yöneticinin işyeri mutluluğunun, verdiği kararlarına da etkisinin olacağı söylenebilir. Yüksek duygusal zekâya sahip kişilerin, kendi duygularını tanıyan, ne istediğini bilen, güçlü ve zayıf yönlerinin farkında olan ve duygularını yöneterek daha sağlıklı kararlar verebilen bireyler oldukları düşünülmektedir. Dolayısıyla yöneticilerin, en doğru kararı verebilmek için, büyük ölçüde duygusal zekâlarından faydalanmaktadır. Buna göre duygusal zekâya sahip bir bireyin, duygularını tanıyan ve kontrol edebilen, başkalarıyla empati kurabilen zorluklarla karşılașıldığında duygusal yeteneklerinden faydalanarak bu süreci idare edebilen bir kişi olması beklenmektedir. Bu yeteneklere sahip bireyin özel hayatında ve iş yaşamında mutluğu yakalamada daha avantajlı olacağı değerlendirilmektedir.

\subsection{Amaç ve Kapsam}

Okullar, toplumu oluşturan tüm bireylerin hayatlarında ortak bir süreci yaşadıkları çok önemli kurumlardır. Bu kurumların yöneticilerinin sevk ve idare ettikleri okul organizasyonlarına kattıkları manevi değer çok kıymetlidir. Onların işyeri mutluluklarının bulundukları tüm okula yansıması tartışılmaz bir gerçektir. Yine okul yöneticisinin tüm uğraşısının özünde insan ilişkileri vardır. İnsan ilişkilerini doğru ve başarılı yönetmenin temelinde ise duygusal zekâ yeteneği vardır. İșyeri mutluluğu ve 
duygusal zekâ ilişkisini incelemek, bu iki önemli konuyu irdelemek, toplumu oluşturan her bireye pozitif anlamda ulaşabilmenin anahtarı niteliğindedir. $\mathrm{Bu}$ araştırmada okul yöneticilerin duygusal Zekâ düzeyleri ile işyeri mutluluğu düzeyleri arasındaki ilişki, niceliksel bir yöntemle incelenmiştir. Katılımcıların cinsiyet, medeni durum, eğitim durumu yaș, yöneticilik süresi gibi demografik bilgilerin yanında; çalıșlan okulun türü, öğretim şekli gibi değişkenlerine göre duygusal zekâ, işyeri mutluluğu ilişkisinin incelenmesi amaçlanmıştır.

Tek başına bilişsel zekâ, gündelik hayattaki problemleri çözmek için yeterli değildir. Örneğin, tehlike arz eden durumlarda, zorluklarla mücadele etmede, eş seçme ve aile kurmada, acı ve kayıplarda, bazı sosyal ilişkilerde bilişsel zekâ tek başına etkin sonuç vermez. Böyle durumlarda duygusal zekâya ihtiyaç vardır. Çünkü duygular insanları belirli durumlarla belirli şekillerde hareket etme konusunda insanları yönlendirir. Güçlüklerle karşı karşıya geldiklerinde nasıl davranacakları konusunda fikir verir. Bunun için duyguları tanımak ve onları anlamak gereklidir. İşletmelerde, eğitim kurumlarında duygusal zekânın önemine gün geçtikçe daha fazla dikkat çekilmektedir. Tüm bu nedenlerden ötürü, duygusal zekânın organizasyonlar üzerinde etkisi son yılların en çok merak uyandıran konularından biri olmuştur. Yönetim ve organizasyon biliminin tarihsel gelişim sürecine bakıldığında, insanı bir makine gibi gören iş ve görev odaklı bir anlayıştan, çalışanı her şeyden önce duygu ve düşünceleri olan bir insan olduğu anlayışına ulaşıldığı görülmektedir. Modern örgütler, amaçlarına ulaşmada en önemli hususun çalışanı motive etmek, işi sahiplenmesini sağlamak ve onun duygu ve düşüncelerini dikkate almak olduğunu keşfetmişlerdir. Çalışan insanın işyeri mutluluğu belki de kurumun başarısında en önemli unsurdur.

Mutluluk hazzı için aşırı hırs sahibi yöneticinin, bulunduğu kuruma zarar verebileceği değerlendirilmektedir. "Mutlu olmaya çabalamak sizi mutsuz kılabilir. Ínat ve ısrarla mutluluk aramak kişiyi öz yıkıma götürüyor" ( https://odatv4.com/mutsuz-insanteroru-14071918.html, Erişim T:16.07.2019). Kişinin kendisini tanımasıyla, diğer bir ifadeyle duygusal zekâsıyla bu tehlike bertaraf edilebilir. Bu araştırma, duygusal zekâ ile işyeri mutluluğu ve arasındaki ilişkiyi inceleyerek, yönetim ve organizasyon bilimine katkı yapacaktır. Literatür incelendiğinde duygusal zekâ, işyeri mutluluğu ve değişkenlerinin birlikte ele alınıp incelendiği bir çalışmaya rastlanmamıștır. Bu kavramları ayrı ayrı ele alınıp incelendiği çalışmalar var olup, eğitim kurumları üzerinden gerçekleștirilmiş çalışmalar sınırlı sayıdadır. Tüm bunlarla birlikte, araştırmacının yıllarca eğitim yöneticiliğinin her kademesinde ve çeşitli okul türlerinde çalışmış olması, alana hâkimiyet, teori ve uygulamanın birleştirilmesi ve verilerin toplanması ve anlamlandırılmasında önemli katkı sağladığı düşünülmektedir. Uygulamanın içindeki araştırmacıların daha verimli sonuçlar elde ettikleri ve bu tür çalışmaların daha değerli olabileceğine dikkat çekilmektedir (Karagül, 2018, s.12). Eldeki bu çalışma;

1-Yöneticinin duygusal zekâ düzeyi ile onun işyeri mutluluğu ve alt boyutları ile arasında anlamlı bir iliş̧inin olup olmadığı,

2-Yöneticinin duygularını tanıma yeteneğinin onun işyeri mutluluğu ve alt boyutları ile anlamlı bir ilişkisinin olup olmadığ

3-Yöneticinin başkalarının duygularını farkında olabilme yeteneğinin onun işyeri mutluluğu ve alt boyutları ile anlamlı bir ilişkisinin olup olmadığı

4-Yine yöneticinin duygularının kullanımı ve duygularını düzenleyebilme yeteneği ile onun işyeri mutluluğu ve alt boyutları ile bir ilişkisinin olup olmadığını ortaya çıkarmak amaçlanmıştır.

Eldeki bu çalışmanın: Yöneticinin duygusal zekâ ve işyeri mutluluğunun önem düzeyinin anlaşılmasına; Okul yönetici seçimi ve yetiştirilmesinde duygusal zekâ kavramının dikkate alınmasına; Okul yöneticiliği faaliyetlerinde, bahsedilen değişkenler 
hakkında farkındalık sağlayarak yönetimde kalitenin arttırılmasına katkı sağlayacağı düşünülmektedir.

\subsection{Kuramsal Arka Plan}

Çalışmanın kuramsal çerçevesini, duygusal zekâ ve işyeri mutluluğu kavramları oluşmaktadır. Öncelikle duygusal zekâ kavramı üzerinde durulacak, ardından ise işyeri mutluluğu kavramı ele alınıp incelenecektir.

\subsubsection{Duygusal Zekâ Kavramı}

Duygusal Zekâ, psikoloji ve diğer sosyal bilim dallarında en çok ilgi çeken ve yoğun olarak araștırılan bir kavramdır. 1995 yılında Daniel Goleman tarafından yayınlanan ve çok ses getiren "Duygusal Zekâ" adlı kitap (Goleman, 2017a, s.6), yoğun ilgi çekmiş ve zekâ alanındaki çalıșmalara yeni bir kapı açmıștır. Goleman bu kitabında, bilișsel zekânın tek başına yeterli olmadığını, bununla birlikte duygusal zekânın da çok önemli olduğunu, kişilerin aile ve sosyal yaşantısını hatta sağlık ilişkilerini de direkt olarak etkilediğini ortaya koymuştur. Goleman'ın ortaya attığı bu yeni kavram, bu zamana kadar yalnızca bilișsel zekâyı temel zekâ türü varsayarak araştırma yapan, bilim insanlarının Zekâ kavramına bakışlarını değiștirmiştir. Böylece zekâ araștırmalarında yeni bir akımı başlatmıştır (Epstein, 1998, s.164).

Daniel Goleman'ın, 1995 yılında yazdığı "Duygusal Zekâ" isimli ve 1998 yılında yazdığı "İşbaşında Duygusal Zekâ" isimli kitaplar dünya çapında çok ilgi görmüş ve duygusal zekâ kavramının akademik anlamda da daha çok tanınması ve çalışılmasına yardımcı olmuştur. Psikoloji literatüründe duygusal zekâyı tanımlayan onlarca açılama olduğu görülmektedir. Bunlardan en önemlilerinden biri yine David Goleman'a aittir. Ona göre duygusal zekâ, "kendini harekete geçirebilme, aksiliklere rağmen yoluna devam edebilme, dürtüleri kontrol ederek tatmini erteleyebilme, ruh halini düzenleyebilme, sıkıntıların düşünmeyi engellemesine izin vermeme, kendisini bașkalarının yerine koyabilme" şeklinde açıklanmaktadır. Kişinin duygularını tanıması, onları kontrol edebilmesi, kendini motive edebilmesi ve empati yapabilmesinin önemi vurgulamaktadır. Örneğin, öfke negatif bir duygudur ve insanlara rahatsızlık verir. Öfke duygusuyla baş etmenin diğer bir yolu ise, daha çok öfkelenmeye sebep olabilecek başka faktörlerin olduğu ortamlardan uzak durmaktır. Örneğin, negatif bir olay yaşandığı zaman o ortamdan uzaklaşmak, öfke uyandıran kişilerden, sakinleşene kadar uzak kalmak, başka şeylerle ilgilenmek öfke duygusunu hafifletecektir. (Goleman, 2017'a, s.124) İşin bu boyutu duyguları kontrol edebilme becerisi ile ilgilidir.

Diğer önemli duygusal zekâ tanımı, ilk duygusal zekâ modelini oluşturan araştırmacılar, Mayer ve Salovey'in (Salovey \& Mayer, 1990, s.185-211) tanımıdır. Onlar duygusal zekâyı, "bireyin kendisinin ve diğerlerinin hislerini ve duygularını izleme, bunlar arasında ayırım yapma ve bu süreçten elde ettiği bilgiyi, düşünce ve davranışlarında kullanabilme yeteneğiyle ilgili olan sosyal zekânın bir alt formudur" şeklinde tanımlamışlardır. Mayer ve Salovey, duygusal zekâyı, duyguyu algılamak, anlamak, ifade etmek, düşünce ve duyguyu kaynaştırabilmek, duyguyu analiz etmek ve kontrol etmek kabiliyetleri ile tanımlanmaktadırlar. İlk duygusal zekâ ölçeğini geliştiren Reuven Bar-On (Bar-On, 1997) ise duygusal zekâyı, "Bilișsel Olmayan Zekâ" (noncognitive intelligence) olarak tanımamış ve "bireyin çevresinden gelen baskı ve taleplerle başarılı şekilde baş edebilmesinde bireye yardımcı olacak, kişisel, duygusal, sosyal yetkinlik ve beceriler dizini" olarak açıklamıştır. Diğer bir önemli duygusal zekâ tanımı ise Cooper ve Sawaf'a (Cooper \& Sawaf, 2003, s.12) aittir. Yazdıkları "Liderlikte Duygusal Zekâ" adlı eserde, organizasyon ve yönetim alanlarında duygusal zekânın etkin kullanımını ve duygusal 
zekâ-liderlik ilişkisini ele almaktadırlar. Onlar duygusal zekâyı, "duyguların gücünü ve hızlı algılayıșını, insan enerjisi, bilgisi, ilişkileri ve etkisinin bir kaynağı olarak duyumsama, anlama ve etkin bir biçimde kullanma yeteneğidir" şeklinde tanımlamışlardır.

Farklı duygusal zekâ tanımlarından da anlaşılacağı gibi, duygusal zekâ, kişinin kendisi ve çevresiyle ilgili davranışlarını etkileyen, kişinin kendini tanıma, motive edebilme, kontrol edebilme, duygularındaki farklılıkları anlayabilme ve kontrol edebilme, isteklerini erteleyebilme, diğer bireylerin duygularını anlayabilme, onlara anlayıș gösterebilme, onlarla etkili ilişkiler kurma ve sürdürebilme kabiliyetlerini içerir. Bunlar öğrenilebilen sosyal ve psikolojik becerilerdir ve bunların yardımıyla kişiler hayattaki doyum ve başarısını üst düzeylere çıkarabilir. Araştırmacılar, bilişsel zekânın (IQ) doğuștan geldiğini, ancak duygusal zekânın her yașta geliştirilebileceğini göstermişlerdir. Bu sebeple duygusal zekâ çok önemlidir (Doğan \& Şahin 2007, s.231-252). O halde, insanların zekâya atfettiği anlamların tümünü kapsayan bir tanım yapmak gerekirse; kişinin kendisinin ve başkalarının duygularını anlayarak, sosyal çevresinden gelen etkilerle baș edebilme ve bu sosyal çevreyi de etkileyebilme yeteneğidir diyebiliriz.

\subsection{2. İşyeri Mutluluğu Kavramı}

Çalışanların mutlulukları, kurumların gelecekleri açısından son derece önem taşımaktadır. Çalışanları neyin mutsuz ettiğini bulup düzeltmekle birlikte, onları gerçek anlamda neyin mutlu ettiğini keşfetmek de organizasyonun sürdürülebilirliği için önemli bir nokta olacaktır. Bundan dolayı, iyi iş ilișkileri kurabilen, insanların hayatlarında bir fark oluşturabilen, organizasyona değer katabilen ve organizasyon paydaşları tarafından takdir edilen çalışanlar; daha fazla içten çalışacaklar ve işyeri mutlulukları da artacaktır. Ayrıca, mutlu çalışanlar organizasyonun temsilcileri olarak, sadece kurumlarını rekabet ortamında temsil etmekle kalmayıp, organizasyonun dışına gönderecekleri pozitif mesajlarla, kurumun dışarıda sergilenen itibarını da yücelteceği söylenebilir. Öte yandan mutsuz insan, çevresini de mutsuz edecektir. Okul yöneticisi konumundaki kişilerin işyerindeki mutsuzlukları; toplumu oluşturan her bireyin hayatının önemli bir bölümünü geçirdiği ve hayatla ilgili en temel bilgi ve davranışları kazandığı okul ortamına da yansiyacaktır.

Artan rekabet ortamının kendini iyice gösterdiği günümüzde, örgütler başarıya ulaşabilmek için çalışanlarının mutluluğunu arttırmaya çaba göstermektedirler. İşletmelerde kişinin mutluluğu, yaptığı işe de yansımaktadır. Yaptığı İşten mutluluk duyan birinin bu mutluluğu hem sosyal hem de toplumsal hayatına yansımaktadır. İnsan günlük yaşamının büyük bir kısmını işinde geçirmektedirler. İşyerinde mutlu olan bireyler, paydaşı oldukları organizasyona çeşitli boyutlarda katkı sunarlar. Örneğin, iş kadını Leyla Alaton iş yerinde mutluluğu şu sözlerle ifade etmektedir: "Aktif hayatımızın yüzde seksenini geçirdiğimiz yerde mutlu olmamak günah olur. Kendimize yapabileceğimiz en büyük kötülük, idare ettiğimiz ama bir türlü mutlu olamadığımız, kendimizi güvende hissettiğimizi zannettiğimiz ama hayatımızı yutan konfor alanlarından çıkamadan kaderimize razı oluvermek. İsyerinde mutlu olmak bir lüks değil, en doğal hakkımızdır. Yine Merhum İş adamı Sakıp Sabancı, "Herkes kendi işini severse, mutlu bir toplum yaratılır." diyerek işyeri mutluluğunun ne denli kapsayıcı olduğunu ifade etmiştir. (Nazlı, 2015, s.49). Mutluluk, bireylerin pozitif duygu durumlarını yansıtan bir kavramdır. Bu kavramın bireyin hayatında önemli bir yer tutan iş yaşamında da çok önemli bir yeri vardır. İş yaşamının bireyin günlük yaşamında önemli bir yer tuttuğundan hareketle, işyeri mutluluğu konusunun incelenmesi daha da önem arz etmektedir. İște mutluluğun bireyin iş dışındaki yaşamına taştığı dikkate alınırsa, genel yaşamındaki mutluluğa da etki ettiğini 
söylemek mümkündür (Keser, 2018, s.43-57). Bu nedenle işyeri mutluluğu kavramı üzerinde çalışılması önem kazanmaktadır.

İşyeri mutluluğu kavramını, genel manada mutluluk kavramından ayırmak gerekir. İşyeri ortamında belirli kurallar, yetki ve sorumluluklar bulunmaktadır. Bu kuralların esnemesi, tartışılması ciddi sorunları beraberinde getirmesi muhtemeldir. İşyeri mutluluğu arayışı, bu temel öğelerden taviz verilmesi anlamına gelmemektedir. Örneğin dersin başladığı saatte sınıfına girmeyen bir öğretmen, sınıf içerisinde başka sıkıntılara neden olmaktadır. Bu öğretmenin uyarılması işyeri mutluluğu düzeyinin düşmesi sonucunu mu doğurmaktadır? İşyeri mutluluğu kavramını açılarken, çalışanın o işyerinde varlık nedeni olan standart beklenti, kural ve görev tanımlarının belirli bir düzeyde ve çalışan tarafından özümsenmiş olması, bunların tartışılma alanı dışında bulundurulması temel nokta olarak ele alınmalıdır. Yapılan araștırmalarda, ölçek geliștirme uygulamalarında bu noktaya vurgu yapılmalıdır.

\section{Yöntem}

$\mathrm{Bu}$ çalışma genel olarak nicel araştırma yöntemlerinden ilişkisel tarama modelinde tasarlanmıştır. İlişkisel tarama modeli, evren hakkında genel bir yargıya varmak amacıyla, evrenin tümü ya da ondan alınacak bir grup, örnek ya da örneklem üzerinde yapılan incelemedir (Köse, 2014, s.110-123). Araștırma evrenin büyüklügü̈, zaman ve maliyet gibi faktörler göz önüne alındığında, bu yöntemin daha faydacı olduğu görülmektedir.

\subsection{Evren ve Örneklem}

Bu araştırmanın evrenini İstanbul ili Avrupa yakasındaki resmi ve özel okullarda görev yapan okul yöneticileri oluşturmaktadır. Okul yöneticisi, okul müdürleri ve okul müdür yardımcılarıdır. Araştırmada erişebilen evrene ulaşılarak veri toplama işlemi gerçekleștirilmiştir. İstanbul İl Milli Eğitim Müdürlüğü yayınladığı 2016-2017 yılı resmi istatistik bilgilerine* göre İstanbul Avrupa yakasındaki 25 ilçede resmi ve özel olmak üzere, ilkokul ortaokul ve lise sayıları 2059 olarak verilmiştir. Bu okulların 631 tanesi ilkokul, 517 tanesi ortaokul ve 411'i lise türündeki okullardır. İlgili okullarda, müdür ve müdür yardımcılarından oluşan toplam yönetici sayısı 5807'dir. Anaokulları, bilim sanat merkezleri, öğretmenevleri, rehberlik araştırma merkezleri yöneticileri araştırmaya dâhil edilmemişlerdir.

Evrenimizdeki okul yöneticilerinden veri toplama araçlarını dolduranlar ise araştırmanın örneklemini oluşturmaktadır. Örneklem seçiminde basit tesadüfü örnekleme yöntemi tercih edilmiştir. Basit tesadüfi örnekleme yöntemine göre, evreni oluşturan her elemanın çalışmaya katılma şansı eșittir. Dolayısıyla her bireye verilen istatistiksel değer aynıdır (Arıkan, 2004, s.141). Bu örnekleme yönteminin kullanılabilmesi için ele alınan problemlerle ilgili bilgilerin evrene göre benzeşik (homojen) olması gerekir (İslamoğlu, 2003, s.147). Mevcut çalışmada evrende yer alan tüm okulların görev tanımları, temel standartları, yönetici seçim süreçleri aynı olduğundan, basit tesadüfi örneklem yönteminin en uygun yöntem olduğu söylenebilir. Veri toplama araçları, evrendeki tüm okul yöneticilerine elektronik ortamda yollanmış, ulaşılabilir konumdaki okullara araştırmacı tarafından gidilerek çalışmaya katılımın arttırılması sağlanmıştır. Gönüllülük esasına bağlı kalınarak araştırmaya katılmak isteyip

\footnotetext{
* İstanbul İl Milli Eğitim Müdürlüğü, Strateji Geliștirme Bölümü. 2016/2017 İstatistik Verileri. İstanbul: İstanbul İl Milli Eğitim Müdürlügü, 2017.
} 
veri toplama araçlarını tamamlayanlar dikkate alınmıştır. Anketleri tam olarak dolduran 404 okul yöneticisine ait veriler analize sokulmuştur.

Araştırmacı, mesleği gereği eğitim kurumlarında çalışmakta, yıllardır okul yöneticiliği yapmaktadır. Dolayısıyla bu alanda geniş bir bilgi, deneyim ve yorum gücüne sahiptir. Bu açıdan bakıldığında da belirtilen alan, evren ve örneklemde çalışmanın daha etkili ve faydalı olduğu düşünülmüştür. Belirtilen nedenlerle bu çalışmanın literatüre önemli katkılar sunması beklenmektedir.

\subsection{Veri Toplama Araçları}

Araştırmada kullanılan veri toplama araçları üç bölümden oluşmaktadır. İlk bölüm, katılımcının demografik özelliklerini içermektedir. Demografik özellikler formunda, Katılımcıların cinsiyet, medeni durum, eğitim durumu yaş, yöneticilik süresi, bulunduğu okulun seviyesi ve yine bulunduğu okulun ikili eğitim olup olmadığına ilișkin sorular yer almaktadır. Anketin diğer iki kısmı, duygusal zekâ ölçeği ve işyeri mutluluğu ölçeğinden oluşmaktadır. Kullanılan ölçeklere ilişkin genel bilgiler ve neden bu ölçeklerin seçildiği açılklanmaya çalışılmıştır.

\subsubsection{Duygusal Zekâ Ölçeği}

Duygusal Zekâ kavramının tüm boyutlarını kapsayan Wong ve Law'un geliştirdiği 16 maddelik Duygusal Zekâ Ölçeği araştırmacılar tarafından ilgi görmektedir (Ilgın, 2010, s.175). Bu çalışmada Wong ve Law tarafından geliştirilen bu "Duygusal Zekâ Ölçeği" kullanılmıştır. Ölçek, Sudak (Sudak, 2011, s.49) tarafından 2011 yılında, doktora tezi bünyesinde Türkçeye uyarlanmıș ve geliștirilmiştir. Sudak tarafından, akademisyenlerin duygusal zekâ düzeyini ölçmek için uygulanan ölçek, 16 sorulu, beşli likert tipinde, dört alt boyuttan oluşmaktadır. Bu ölçeğin kullanılmasının sebebi, eldeki bu çalışmada tasarlanan modeli ve bu modelin bileșenlerini iyi karşılıyor olması, geliştirildiği ve Türkçe'ye uyarlandığı çalışmada güvenilirliğinin yüksek çıkması $(\alpha=0.91)$ ve bireysel değerlendirmeye uygunluğudur (Ilgın, 2010, s.174). Ölçeğin alt boyutları ve bu boyutları ölçen anket maddeleri ile ölçeğin güvenilirlik analizini içeren Cronbach Alpha, ortalama ve standart sapma değerleri Tablo-1'de gösterilmiștir.

\begin{tabular}{|l|l|l|l|l|}
\hline Duygusal Zekâ ölçeği Alt Boyutları & $\begin{array}{l}\text { İlişkili } \\
\text { maddeler }\end{array}$ & $\begin{array}{l}\text { Cronbach's } \\
\text { Alpha }\end{array}$ & $\overline{\mathbf{X}}$ & S.s \\
\hline $\begin{array}{l}\text { Kendi duygularının farkında olma } \\
\text { (DFO) }\end{array}$ & Madde 1,2,3,4 & 0.90 & 17.51 & 2.51 \\
\hline $\begin{array}{l}\text { Başkalarının duygularının farkında } \\
\text { olma (BDFO) }\end{array}$ & Madde 5,6,7,8 & 0.81 & 17.16 & 2.31 \\
\hline Duygu kullanımı (DUD) & $\begin{array}{l}\text { Madde } \\
9,10,11,12\end{array}$ & 0.88 & 16.63 & 2.58 \\
\hline Duygu düzenlemesi (DUK) & $\begin{array}{l}\text { Madde } \\
13,14,15,16\end{array}$ & 0.80 & 15.53 & 2.84 \\
\hline
\end{tabular}

Tablo-1: Duygusal Zekâ Ölçeği Alt Boyutları Madde Dağılımı ve Güvenilirlik Analizi.

Ölçeğin ilk dört maddesi bireysel duygusal değerlendirme boyutunu, ikinci dört maddesi başkalarının duygularını değerlendirme boyutunu, üçüncü dördüncü maddesi duyguları ayarlama boyutunu ve dördüncü dört maddesi de duyguları kullanma boyutunu temsil etmektedir. Ölçeğin her bir boyutun maddelerinin güvenilirliğini temsil eden Cronbach alfa değerleri sırasıyla 0.90; 0.81; 0.88 ve 0.80 olarak bulunmuştur. Duygusal 
zekâ ölçeği genel güvenilirlik düzeyi 0.90 olarak bulunmuştur. Ölçek, kesinlikle katılmıyorum "1" puan en düşük derece, kesinlikle katılıyorum "5" puan en yüksek dereceyi ifade eden $5^{\prime}$ li likert tipinde olup, soruların tamamı olumludur. Kesinlikle katılıyorum cevabı (5), ölçekte aranan duygusal zekâ düzeyinin en yüksek olduğunu, kesinlikle katılmıyorum (1) duygusal zekâ düzeyinin en düşük olduğu düzeyi ifade etmektedir. Ölçekten elde edilen puanların yüksekliği, duygusal zekâ seviyesi ile doğru orantılıdır. Yani ölçekten elde edilen puan ne kadar yüksekse, duygusal zekâ seviyesi de o oranda yüksektir. Araştırmanın bulgular bölümünde duygusal zekâ düzeyinin yüksekliği ile değişken ilişkileri ve hipotezler incelenmiştir.

\subsection{2. İşyeri Mutluluğu Ölçeği}

Araştırmada, okul yöneticilerinin işyeri mutluluğunu ölçmek için, Nazlı'nın "Hizmet Sektöründe Kurumsal Yönetimin İște Mutluluk Üzerine Etkisi" isimli Doktora tezinde geliştirdiği İşyeri Mutluluğu Ölç̧eği kullanılmıștır (Nazlı, 2015, s.81). Ölçek, turizm İşletmelerinde çalışanların işyeri mutluluğunu ölçmek için kullanılmıştır. Nazlı doktora tezinde, işyeri mutluluğu ölçeğini oluştururken; Allen ve Meyer 'in (Allen \& Meyer, 1990, s.1-18) örgütsel bağlılık ölçeği Karatepe ve Olugbade'nin (Karatepe \& Olugbade, 2009, s.504-512) ișe kenetlenme (iş şevki, iși özümseme ve ișe adanma) ölçeği ile Hackman ve Oldham'ın (Hackman \& Oldham, 1980, s.78-80) iş tatmini ölçeğini birleștirmiştir. Nazlı, ölçeğin güvenilirliğini temsil eden Cronbach alfa değerini 0.90 olarak belirlemiştir (Nazlı, 2015, s.82).

Eldeki çalışma için kullanılan bu ölçek, okul yöneticileri için özüne sadık kalınarak güncelleştirilip şu șekilde uyarlanmıștır: " İşim bana güvenliğimi sağlar" sorusunun amaca hizmet etmediği düşünüldüğünden, "İşyerimde rekabet etme fırsatı vardır" sorusu, yöneticinin aynı işyerinde rekabet edeceği düzeyde yeterince birim bulunmadığından, "İşimdeki gözetimin ve denetimin kalitesi iyidir" sorusu ise, denetim ve gözetimi yapanın da okul yöneticisinin kendisi olması gerekçesiyle ölçekten çıkarılmıștır. "Bana göre işim zorludur" sorusu, anlamını sabitlemek için "Yaptığım iş aslında zor bir iștir" şeklinde düzenlenmiştir. Ölçekte kodlanan "ne katılıyorum ne katılmıyorum" cevabı ise "kararsızım" olarak değiștirilmiştir.

Ölçek, 35 sorulu, beşli likert tipinde, 5 alt boyuttan oluşmaktadır. Ölçeğin alt boyutları ve bu boyutları ölçen anket maddeleri ile ölçeğin güvenilirlik analizini içeren Cronbach Alpha, ortalama ve standart sapma değerleri Tablo-2'de gösterilmiştir.

\begin{tabular}{|c|c|c|c|c|}
\hline $\begin{array}{l}\text { İşyeri Mutluluğu Ölçeği } \\
\text { Boyutları }\end{array}$ & İlişkili maddeler & $\begin{array}{l}\text { Cronbach's } \\
\text { Alpha }\end{array}$ & $\overline{\mathbf{X}}$ & S.s \\
\hline Örgütsel bağlılık (ÖRB) & Madde $1,2,3,4,5,6,7,8$ & 0.92 & 31.26 & 4.96 \\
\hline İş şevki (İŞŞ) & Madde $9,10,11,12,13,14$ & 0.82 & 25.60 & 3.92 \\
\hline İşi özümseme (íşö) & Madde $15,16,17,18,19$ & 0.91 & 18.75 & 3.78 \\
\hline İşe adanma (İŞA) & Madde $20,21,22,23,24$ & 0.79 & 22.07 & 2.71 \\
\hline \multirow[t]{2}{*}{ İş tatmini (İŞT) } & $\begin{array}{l}\text { Madde } \\
25,26,27,28,29,30,31,32,33,34,35\end{array}$ & 0.76 & 40.69 & 7.38 \\
\hline & & 0.87 & & \\
\hline
\end{tabular}

Tablo-2: İşyeri Mutluluğu Ölçeği Boyutları ve Madde Dağılımı

Ölçeğin ilk sekiz maddesi örgütsel bağlılık boyutunu, sonraki altı maddesi iş şevki boyutunu, devamındaki beș maddesi ișe adanma boyutunu, son on madde ise iș tatmini 
boyutunu temsil etmektedir. İşyeri mutluluğu ölçeği genel güvenilirlik düzeyi 0.92 olarak bulunmuştur. Ölçeğin ÖRB alt boyutu güvenilirlik düzeyi 0.82 ; IŞŞ boyutu güvenilirlik düzeyi 0.91; İșö boyutu güvenilirlik düzeyi 0.79; alınan İŞA boyutu güvenilirlik düzeyi 0.76; alınan şans eseri İ̧̧ boyutu güvenilirlik düzeyi 0.87 olarak bulunmuștur. Elde edilen bu verilere göre, ölçeğin güvenirlik düzeyinin oldukça yüksek olduğu görülmektedir.

\section{Bulgular}

Öncelikle, Araștırmaya katılan okul yöneticilerinin demografik özelliklerine ilișkin bulgular ortaya çıkarılmıştır. Ardından, okul yöneticilerinin duygusal zekâ ölçeği alt boyutları ile işyeri mutluluğu ölçeğinden alınan puanlar arasında anlamlı bir ilişki olup olmadığını anlamak için testlerden alınan puan ortalamaları korelasyon analizi ile incelenmiştir. Elde edilen bulgular önce duygusal zekâ alt boyutlarının genel manada ișyeri mutluluğu ilișkisi ortaya çıkarılmıștır. Ardından da İșyeri mutluluğu alt boyutlarının genel manada duygusal zekâ arasındaki ilișki incelenmiș ve analiz edilmiștir.

\subsection{Katılımcıların Demografik Özelliklerine İliş̧kin Bulgular}

İstanbul Avrupa yakasındaki okul yöneticileri üzerinde yürütülen bu çalışmaya, 98 (\%24.2) kadın, 306 (\%75.7) erkek olmak üzere toplam 404 okul yöneticisi katılmıştır. Katılımcıların 300 (\%74.2)'ü evli iken, 104 (\%25.7)'ü bekârdır. 50 katılımcı (\%12.3) 2030 yaş aralığında, 165 katılımcı (\%40.8) 31-40 yaş aralığında, 129 katılımcı (\%31.9) 4150 yaş aralığında ve 60 katılımcı (\%14.8) ise 51 yaş ve üstü aralığındadır. Okul yöneticilerin eğitim durumlarına bakıldığında, 248 kișinin (\%61.4) lisans mezunu, diğer 156 kişinin (\%36.6) ise lisansüstü eğitim aldığı görülmüștür. Okul yöneticilerinin görev yaptıkları okulların türlerine bakıldığında 226'sının (\%55.9) ilkokulda, 89'unun (\%22) ortaokulda, 89'unun (\%22) ise lisede görev yapmaktadır. Ayrıca okul yöneticilerinin 316’sı (\%78.2) ikili eğitim yapan okullarda, kalan 88'i (\%21.7) ise tekli/normal eğitim yapan okullarda görev yapmaktadırlar.

\subsection{Duygusal Zekâ Ölçeği Alt Boyutları ile İşyeri Mutluluğuna İlişkin Bulgular ve Analizi}

Elde edilen veriler SPSS programı yardımı ile analiz edilmiş ve okul yöneticilerinin duygusal zekâ ölçeği alt boyutları ile işyeri mutluluğuna ilişkin bulgular ve analizi tablo 3 de gösterilmiştir.

\begin{tabular}{|c|c|c|c|c|c|c|c|c|c|c|c|}
\hline & $\bar{X}$ & S.s. & DFO & BDFO & DUK & DUD & ÖRB & işs & işö & işA & işT \\
\hline DFO & 17.51 & 2.51 & 1 & $0.50^{* *}$ & $0.57^{* *}$ & $0.34^{* *}$ & $0.32^{* *}$ & $0.52^{* *}$ & $0.31^{* *}$ & $0.22^{*}$ & 0.05 \\
\hline BDFO & 17.16 & 2.31 & $0.50^{* *}$ & 1 & $0.41^{* *}$ & $0.42^{* *}$ & $0.45^{* *}$ & $0.53^{* *}$ & $0.36^{* *}$ & $0.39^{* *}$ & $0.20^{*}$ \\
\hline DUK & 16.63 & 2.58 & $0.57^{* *}$ & $0.41^{* *}$ & 1 & $0.54^{* *}$ & $0.41^{* *}$ & $0.63^{* *}$ & $0.45^{* *}$ & $0.35^{* *}$ & $0.25^{* *}$ \\
\hline
\end{tabular}




\begin{tabular}{|c|c|c|c|c|c|c|c|c|c|c|c|}
\hline DUD & 15.53 & 2.84 & $0.34^{* *}$ & $0.42^{* *}$ & $0.54^{* *}$ & 1 & $0.38^{* *}$ & $0.57^{* *}$ & $0.42^{* *}$ & $0.36^{* *}$ & $0.36^{* *}$ \\
\hline ÖRB & 31.26 & 4.96 & $0.32^{* *}$ & $0.45^{* *}$ & $0.41^{* *}$ & $0.38^{* *}$ & 1 & $0.58^{* *}$ & $0.48^{* *}$ & $0.46^{* *}$ & $0.46^{* *}$ \\
\hline İșș & 25.60 & 3.92 & $0.52^{* *}$ & $0.53^{* *}$ & $0.63^{* *}$ & $0.57^{* *}$ & $0.55^{* *}$ & 1 & $0.61^{* *}$ & $0.51^{* *}$ & $0.36^{* *}$ \\
\hline iş̧ö & 18.75 & 3.78 & $0.31^{* *}$ & $0.36^{* *}$ & $0.45^{* *}$ & $0.42^{* *}$ & $0.48^{* *}$ & $0.61^{* *}$ & 1 & $0.52^{* *}$ & $0.43^{* *}$ \\
\hline İŞA & 22.07 & 2.71 & $0.22^{* *}$ & $0.39^{* *}$ & $0.35^{* *}$ & $0.36^{* *}$ & $0.46^{* *}$ & $0.51^{* *}$ & $0.52^{* *}$ & 1 & $0.38^{* *}$ \\
\hline İșT & 40.69 & 7.38 & 0.05 & $0.20^{*}$ & $0.25^{* *}$ & $0.36^{* *}$ & $0.46^{* *}$ & $0.36^{* *}$ & $0.43^{* *}$ & $0.38^{* *}$ & 1 \\
\hline
\end{tabular}

Tablo-3: Duygusal Zekâ Ölçeği Alt Boyutları ile İşyeri Mutluluğu Puan Ortalamalarına Ait Korelasyon Analizi Sonuçları

Tablo-3'de okul yöneticilerinin duygusal zekâ ölçeğinin DFO alt boyutu ile; işyeri mutluluğu alt boyutlarından, örgütsel bağlılık (ÖRB) alt boyutu arasında anlamlı pozitif bir korelasyon ( $\mathrm{r}=0.32 ; \mathrm{p}<0.01)$, iş şevki (ISSŞ) alt boyutu ile arasında anlamlı pozitif bir korelasyon ( $r=0.52 ; p<0.01)$, işi özümseme (İșÖ) alt boyutu ile arasında anlamlı pozitif bir korelasyon $(\mathrm{r}=0.31 ; \mathrm{p}<0.01)$, işe adanma (ISSA) alt boyutuyla anlamlı pozitif bir korelasyon $(\mathrm{r}=0.22 ; \mathrm{p}<0.01)$ bulunmuştur. Öte yandan, DFO ile iş tatmini (IŞT) alt boyutu ile anlamlı bir korelasyon bulunmamıştır ( $\mathrm{r}=0.05$; $\mathrm{p}<0.01)$. Okul yöneticilerinin duygusal zekâ ölçeğinin BDFO alt boyutu ile; işyeri mutluluğu alt boyutlarından, örgütsel bağlılık (ÖRB) alt boyutu arasında anlamlı pozitif bir korelasyon ( $\mathrm{r}=0.45 ; \mathrm{p}<0.01)$, iş şevki (İŞŞ) alt boyutu ile arasında anlamlı pozitif bir korelasyon ( $\mathrm{r}=0.53$; $\mathrm{p}<0.01)$, iși özümseme (IŞÖ) alt boyutu ile arasında anlamlı pozitif bir korelasyon ( $\mathrm{r}=0.36$; $\mathrm{p}<0.01)$, işe adanma (IŞSA) alt boyutuyla anlamlı pozitif bir korelasyon ( $\mathrm{r}=0.39 ; \mathrm{p}<0.01)$, iş tatmini (IŞT) alt boyutu ile de anlamlı pozitif bir korelasyon bulunmamıștır $(\mathrm{r}=0.20 ; \mathrm{p}<0.01)$. Okul yöneticilerinin duygusal zekâ ölçeğinin DUK alt boyutu ile; işyeri mutluluğu alt boyutlarından, örgütsel bağlılık (ÖRB) alt boyutu arasında anlamlı pozitif bir korelasyon $(\mathrm{r}=0.41 ; \mathrm{p}<0.01)$, iş şevki (ISSŞ) alt boyutu ile arasında anlamlı pozitif bir korelasyon ( $\mathrm{r}=0.63 ; \mathrm{p}<0.01)$, işi özümseme (İŞö) alt boyutu ile arasında anlamlı pozitif bir korelasyon ( $\mathrm{r}=0.45 ; \mathrm{p}<0.01)$, işe adanma (İŞA) alt boyutuyla anlamlı pozitif bir korelasyon ( $\mathrm{r}=0.35$; $\mathrm{p}<0.01$ ), iș tatmini (IȘT) alt boyutu ile de anlamlı pozitif bir korelasyon bulunmamıștır $(r=0.25 ; \mathrm{p}<0.01)$. Okul yöneticilerinin duygusal zekâ ölçeğinin DUD alt boyutu ile; işyeri mutluluğu alt boyutlarından, örgütsel bağlılık (ÖRB) alt boyutu arasında anlamlı pozitif bir korelasyon $(\mathrm{r}=0.38 ; \mathrm{p}<0.01)$, iş șevki (İş̧̦) alt boyutu ile arasında anlamlı pozitif bir korelasyon ( $\mathrm{r}=0.57 ; \mathrm{p}<0.01)$, işi özümseme (İşö) alt boyutu ile arasında anlamlı pozitif bir korelasyon $(\mathrm{r}=0.42 ; \mathrm{p}<0.01)$, işe adanma (ISSA) alt boyutuyla anlamlı pozitif bir korelasyon $(\mathrm{r}=0.36$; $\mathrm{p}<0.01$ ), iş tatmini (İșT) alt boyutu ile de anlamlı pozitif bir korelasyon bulunmamıștır $(\mathrm{r}=0.36 ; \mathrm{p}<0.01)$.

Okul yöneticilerinin duygularının farkında olma düzeyleri ile işyeri mutluluğu düzeyleri arasında pozitif bir ilişki bulunmuştur. Kişinin kendi duygularını tanıması ve anlamasının, işyeri mutluluğu algısını da pozitif yönde etkiliyor olması olası bir sonuçtur. Yapılan bilimsel çalışmalar, duygusal zekâ ile psikolojik iyi olma akıl/ruh sağlığı ve yaşam 
doyumu arasında pozitif yönde ilişki olduğunu belirtmektedirler (Neçare, 2017, s.137). Araştırma bulgularını destekler nitelikte başka çalışmalar da mevcuttur. Sudak tarafından, akademik personel üzerinde yapılan araştırmada duygusal zekâ düzeyi ile işyeri mutluluğu arasında güçlü bir ilişki olduğu bulunmuştur (Sudak, 2011, s.82). Literatürdeki diğer çalışmalar da bu durumu destekler niteliktedir. Örneğin Wong ve Lav, yaptıkları araştırmada, duygusal zekâ arttıkça, işyeri mutluluğunun da arttığını kanıtlamışlardır (Wong \& Law, 2002, s.243-274). Okul yöneticilerinin duygusal zekâ bileșenlerinden duygularının farkında olma boyutu ile işyeri mutluluğu alt boyutlarından sırasıyla; iş şevkinin de arttığı, örgütsel bağlılıklarının da arttı̆̆ı ve işini daha fazla özümsediği bulunmuştur. Bunların yanında, yöneticinin duygularının farkında olma becerisi yükseldikçe, işinden daha fazla tatmin düzeyine ulaştığı saptanmıştır. Bireyin duyguları, sosyal yaşamı olduğu kadar iş hayatını da önemli ölçüde etkilemektedir. Duygusal zekâ bileșenleri içinden duygularını iyi tanıyan, duygularının olayları nasıl etkilediğinin farkında olan ve onları etkili biçimde kullanabilen bireyler, çalısma yaşamalarında daha basarılı olabilmektedir (Demir, 2009, s.189). Çünkü kişinin tüm bu duygusal süreçlerini yasama biçimi onun duygusal zekâsını olusturmaktadır. Bu nedenle duygularını tanıyan yöneticilerin daha kolay iş doyumu sağlaması beklenmektedir.

Okul yöneticisinin başkalarının duygularının farkında olma düzeyi ile işyeri mutluluğu düzeyi arasında orta düzeyde anlamlı bir ilişki bulunmuştur. Başkalarının duygularının farkında olma, onları anlama, ayırt edebilme ve çözümleyebilme yeteneği yüksek olan okul yöneticisinin, işyeri mutluluğu düzeyinin de aynı derecede yüksek olduğu söylenebilir. Empati düzeyi yüksek yöneticinin, diğerlerine göre işyerinde daha mutlu olması beklendik bir sonuçtur. Empati yeteneğinin, organizasyon işleyişinde ortaya çıkan birey kaynaklı sorunların yönetici tarafından anlaşılmasını, nedenlerinin bulunmasını sağlayan bir yetenek olduğu söylenebilir. Organizasyondaki insan kaynaklı defoların sebeplerinin anlaşılması ise, yöneticinin stresini azaltabilir. Neden bu hatayı yapıyor sorusu stres yapan bir durumdur. Empati ile sebep anlaşılabilir ve bu algoritmanın çözümü stresi azaltır, çözüm için doğru noktanın tespitini sağlayabilir. Nereden başlanması gerektiğini işaret eder. Empatinin, sorunların çözümünde önemi tartışılmaz. Başkalarının duygularının farkında olma yeteneği yüksek olan okul yöneticilerinin, örgütsel bağlılıklarının da aynı şekilde yüksek olduğu, işini yapmaktan daha fazla şevk duyduğu ve aynı şekilde işini daha fazla özümseyip işine daha fazla adanmışlık hissettiği bulunmuştur. Sözü edilenler kadar benzeri bir paralellik olmasa da, başkalarının duygularının farkında olma becerisi yüksek olan yöneticilerin iş tatminlerinin de kısmen arttığı gözlenmiştir. Başkalarının duygularını anlama yeteneğinin, işyerindeki ilişkilerin düzenlenmesine katkısı ve iş yaşamındaki olumlu etkileri oldukça önem arz etmektedir (Bailie \& Ekermans, 2006, s.3-11). Bu bakımdan, başkalarının duygularının farkında olma düzeyi yüksek yöneticinin, örgütsel bağlılığının, iș şevkinin, ișini özümsemesinin, iș tatmini ve ișine adanma düzeyinin de yüksek olması literatürle de paralellik göstermekte olup, aynı zamanda beklendik bir sonuç olarak değerlendirilmektedir.

Okul yöneticisinin duygularını kullanma becerisi ile işyeri mutluluğu düzeyi arasında orta düzeyde anlamlı bir ilişki olduğu saptanmıştır. Duygularını kullanma yeteneği gelişmiş ve bu anlamda daha iyi olan yöneticinin, işyerinde de diğerlerine göre daha mutlu olduğu söylenebilir. Okul yöneticilerinin duygularını kullanabilme yetenekleri arttıkça çalıştığı örgüte hissettiği bağlılığın, iș șevkinin, işi özümsemesinin de arttığı, aynı şekilde ișe adanma düzeyinin de arttığı bulunmuştur. Karşılaştığı yeni durum ve olaylar karşısında duygularını kullanabilme yeteneği yüksek olan yöneticinin, az da olsa iş tatmininin de arttığı saptanmıştır. Organizasyonlarda hem olumlu hem de etkili duygular olusturabilmek ve bu yolla örgütleri olumlu olarak yönetebilmek için gerekli olanların iyi bilinmesi ve bu unsurların öneminin iyi anlaşılması yarar sağlamaktadır. Bu faktörlerin 
organizasyonlarda olumlu bir iklim olusturabilmeleri için kendilerine ait rolleri yerine getirmeleri ve karşılıklı etkilesim içerisinde olmaları iyi bir duygu yönetimi için elzem şartlar arasında sayılmaktadır (Barutcugil, İsmet, 2004). Organizasyonlarda bu yönde olumlu bir iklimi oluşturmayı sağlayan duygusal zekâ faktörlerinden önemli bir tanesi de duyguları doğru zamanda ve doğru yerde kullanabilme becerisidir.

Okul Yöneticisinin duyguları düzenleme yeteneği ile işyeri mutluluğu düzeyi arasında orta düzeyde anlamlı bir ilișki tespit edilmiştir. Daniel Goleman da "İşyerinde duygusal zekâ" adlı kitabında bir bütün olarak bu ilișkinin varlığına işaret etmektedir. Okul yöneticisinin duyguları kullanabilme yeteneği yüksek ise, aynı şekilde işyeri mutluluğu düzeyi de yüksektir denilebilir. Duygu kullanımı yeteneğinin, işyeri iyilik algısını pozitif yönde etkilediği söylenebilir. Duygularını düzenleyebilme yetisinin tüm algı ve dış dünyayı olumlu okuyup yorumlamayı sağladığı düşünüldüğünde, ilgili sonucun beklendik bir sonuç olduğu söylenebilir. Diğer pek çok çalışmada da duygusal zekâ düzeyleri ile iş doyumu düzeyleri arasında, pozitif ve anlamlı bir ilişki olduğu bulunmuştur (Şahin vd., 2011, s.986). Duygularını düzenleme konusunda yetenekli olan okul yöneticilerinin sırasıyla örgütsel bağlılıklarının, iş şevklerinin, işlerini özümseme seviyelerinin, ișe adanma ve iş tatminlerinin de o derece iyi olduğu sonucuna ulaşılmıştır. Duyduklarını anlayıp, onları karşılaşılan yeni durumlara karşı düzenleyebilen yöneticilerin, iş tatmini, işe adanma, işine bağlı̆̆ gibi tüm işyeri mutluluğu bileşenleri üzerinde olumlu etkilerinin olduğu ifade edilmektedir (Demir, 2009, s.40). Duygu düzenleme, duygularını kontrol altına almayı ve onlara hükmedebilmeyi ifade etmektedir. $\mathrm{Bu}$ açıdan bakıldığında, öfkesini, hırsını, aşırı coşkunluğunu ve diğer uç veya zararlı duygularına hükmedebilen bir yöneticinin işinden daha fazla haz, tatmin ve doyum alabileceği, işine daha bir bağlanacağı ve şevk duyacağı beklenen bir sonuçtur denilebilir.

\section{Tartışma ve Sonuç}

Okul yöneticilerinin duygusal zekâ düzeyleri ile işyeri mutlulukları arasında orta düzeyde anlamlı bir ilişki bulunmuştur. Duygusal zekâ arttıkça, işyeri mutluluğu da artar. Yine tam tersi olarak duygusal Zekâ düzeyinde bir azalma olduğunda, işyeri mutluluğu düzeyinin de buna paralel olarak düştüğü söylenebilir. Duygusal zekâyı oluşturan tüm alt boyutlar ile işyeri mutluluğu arasında pozitif ilişkiler saptanmıştır. Duygularının farkında olan okul yöneticisinin işyeri mutluluğunun da yüksek olduğu, başkalarının duygularının farkında olan okul yöneticisinin işyeri mutluluk düzeyinin yüksek olduğu, duygularını kullanabilme becerisi arttıkça, işyerinde daha fazla mutlu oldukları, duygu düzenleme yetisinin gelişmiş olması ile paralel bir şekilde işyerinde daha fazla mutlu olabildikleri sonucuna ulaşılmıștır. Aynı șekilde okul yöneticilerinin ișyeri mutluluğu ile duygusal zekâ düzeyi arasında anlamlı ve pozitif bir ilişki bulunmuştur. Örgütsel bağlılığı yüksekokul yöneticisinin duygusal zekâ düzeyinin de yüksek olduğu, işini özümsediği durumlarda duygusal zekânın da yükseldiği, işine adanma düzeyi yükseldikçe duygusal zekâsının da yükseldiği ve iş şevki arttıkça duygusal zekâ yetilerinin de arttığı söylenebilir. Aynı șekilde iş tatmini artan okul yöneticisinin duygusal zekâ düzeyinin de arttığı saptanmıştır. İşyeri mutluluğu boyutlarının her biri arttıkça duygusal zekâ düzeylerinde de bir artış olduğu, azaldıkça da tam tersi bir durumun söz konusu olduğu söylenebilir.

Yine okul yöneticilerinin duygusal zekâ bileșenlerinden duygularının farkında olma becerisi arttıkça işyeri mutluluğu bileşenlerinden sırasıyla; örgütsel bağlılığın, işi özümsemelerinin, işe adanma düzeylerinin, iş şevklerinin de arttığı görülmüştür. Öte yandan, iş tatminleri ile arasında anlamlı bir ilişki saptanmamıştır. Özetle, duygularının farkında olma düzeyi yüksek olan okul yöneticisinin örgütsel bağlılığı, işi özümsemesi, işe adanmışlığı, iş şevki de artmaktadır. Ancak yöneticinin duygularının farkında olma düzeyleri ile iş tatminleri arasında bir ilişki yoktur. Bununla birlikte, okul yöneticilerinin 
duygusal zekâ bileșenlerinden bașkalarının duygularının farkında olma yeteneği arttıkça işyeri mutluluğu arasında pozitif bir korelasyon saptanmıştır. Özetle, başkalarının duygularının farkında olma yetisi yüksek olan okul yöneticilerinin işyerinde daha mutlu oldukları bulunmuştur. Aynı şekilde, okul yöneticilerinin duygusal zekâ bileșenlerinden duygularını kullanabilme yetenekleri arttıkça işyeri mutluluğunun da yükseldiği saptanmıştır. Duygu kullanımı yeteneği gelişmiş okul yöneticilerinin işyerinde diğerlerine göre, daha mutlu oldukları görülmüştür. Duygularını kullanabilme yeteneğinin, mevcut çalışma ortamlarındaki tüm faktörler üzerinde olumlu etkilerinin olması muhakkaktır.

Çalışmamız İstanbul İli Avrupa yakasındaki resmi ve özel okul yöneticileri üzerinde uygulanmıştır. Her bölgenin, ilçenin toplumsal yapısı değişiklik göstermektedir. Her bir okulun çevresel değişkenleri oldukça farklıdır. Bir ilçede sığınmacı ağırlıkta iken, bazı ilçelerde sığınmacı sayısı çok az olabilmektedir. Yine veli sosyo ekonomik düzeyi okulun bulunduğu bölgeye göre değişiklik göstermektedir. Ayrıca, araștırmamız sınırlı değişkenler üzerinde uygulanmıştır. Bu nedenlerle her okulun yöneticisinde ya da okul habitatında benzer sonuçları söylemek mümkün olmayacaktır. Bu durum araştırmamızın sınırlılığıdır. Duygusal zekâ, İșyeri mutluluğu ilişskisini inceleyen benzeri araștırmalar öğretmenler üzerinde de uygulanabilir. Okul yöneticilerinin duygusal zekâ düzeylerini arttırmaya yönelik eğitim programları geliştirme amaçlı araştırma ve uygulamalar geliştirilebilir. Okul yöneticisi seçimi, öğretmen mülakatları ve eğitim ortamlarında bulunacak her paydaş için özellikle duygusal zekâ düzeylerini ölçmeye yarayan ölçekler, örnek olay üzerinde değerlendirme çalışmaları yapılabilir. Bundan sonraki araştırmalarda, farklı çalıșma alanlarında birden çok sektör seçilerek, farklı örneklem kütleleri ile çalışmalar yapılabilir. Bu çalışmalar kamu ve özel sektör olmak üzere ayrı ayrı da yürütülebilir. Duygusal zeka ve mutluluk ilișkisi günümüzde akademisyenlerin ve iş dünyasının ilgisini çeken bir konu olmaya başlamıştır*. Gerçekleștirilen araştırmaların bulgularına göre, çalışanların duygusal zekâlarının, işyeri mutlulularının düzeylerinin geliştirilmesine yönelik eğitimler planlanabilir. Okul yönetiminin özünü insan ilişkileri oluşturmaktadır. Bu bakımdan okul yöneticisinin en ihtiyaç duyduğu yeteneğin duygusal zekâ yeteneği olduğu söylenebilir. Öte yandan mutsuz yöneticinin duygu durumunun bulunduğu kurumunu iklimini de etkileyeceği gibi, işyerinde mutlu yönetici, yönettiği kurumun iklimine de pozitif katki sunacaktir. Bu bakımdan okul yöneticilerinin duygusal zekâ düzeylerini yükseltme amaçlı çalışmalara yoğunlaşılabilir, eğitim programlari geliştirilebilir.

\section{KAYNAKÇA}

ALLEN, N. J. \&. MEYER, J. P. (1990) The measurement and antecedents of affective, continuance and normative commitment to the organization, Journal of Occupational Psychology, Cilt: 63, 1-18.

ARIKAN, R. (2004). Araştırma teknikleri ve rapor hazırlama. Ankara, Asil Yayın.

\footnotetext{
* Son yıllarda işletmelerde duygusal zekâ üzerine eğitimler planlanmakta olduğu görülmektedir. (https://tr.pearson.com/tr/kurumsal-egitim/pearson-professional-programs/programlardersler/emotional-intelligence.html), (https://www.hayatinritmi.com.tr) Yine Mutluluk ve duygusal zekâ ilişki üzerine yoğunlaşan araştırmalar dikkat çekmektedir (https://bccturkey.com/mutluluk-acisindan-dijital-cagda-duygusal-zeka-neden-kilit-onemdedir/), (https://www.dr.com.tr/Kitap/Mutluluk-Duygusal-Zeka/Kolektif/Egitim-Basvuru/PsikolojiBilimi).
} 
BAILIE, K. \& EKERMANS, G. (2006) “An Exploration of the Utility of a Self-Report Emotional Intelligence Measure", E-Journal of Applied Psychology: Emotional Intelligence, Cilt: 2, 2, 3-11.

BAR-ON, R. (1997). Emotional Quotient Inventory: Technical Manual, Toronto, Multi Health Systems. Yayınları.

BARUTÇUGIL, İ. (2004) Organizasyonlarda Duyguların Yönetimi, Istanbul, Kariyer

CHI-SUM, W. \& LAW K. S. (2002), The effects of leader and follower emotional intelligence on performance and attitude: An exploratory study, Leadership Quarterly, Cilt: 13, p.243-274

COOPER, R. K. \& SAWAF, A., (1997), Liderlikte Duygusal Zekâ, (Çev. Zelal Bedriye Ayman-Banu Sancar), Üçüncü Basım: Eylül 2003, İstanbul, Sistem Yayıncılık,

COTE, S. (2014), Emotional intelligence in organizations. Annual Review of Organizational Psychology and Organizational Behaviour, Cilt: 1, 459-88.

DEMIR, M. (2009), Konaklama İșletmelerinde Duygusal Zekâ, Örgütsel Sapma,

Çalısma Yasamı Kalitesi ve İșten Ayrılma Eğilimi Arasındaki İlișkinin Analizi, Yayımlanmıș Doktora Tezi, Dokuz Eylül Üniversitesi, Sosyal Bilimler Enstitüsü, İzmir.

DEMİRÖZ, E. (2019), "Mutsuz İnsan Terörü", https://odatv4.com/mutsuz-insanteroru-14071918.html, (Erişim Tarihi: 16.07.2019)

DOĞAN, S. \& ŞAHINN F. (2007), "Duygusal Zekâ: Tarihsel Gelişimi ve Örgütler İçin Önemine Kavramsal Bir Bakıș”, Çukurova Üniversitesi Sosyal Bilimler Enstitüsü Dergisi, Cilt: 16, 1, ss.231-252.

EPSTEIN, S. (1998), Constructive Thinking: The Key to Emotional Intelligence,

Westport, CT, USA, Greenwood Publishing Group, Incorporated.

GOLEMAN, D. (2017). Duygusal Zekâ (47. baskı b.). (B. S. Yüksel, Çev.) İstanbul,

Varlık Yayınları.

GOLEMAN, D. (2017), İşbaşında Duygusal Zekâ, (17. Baskı) (Ceviri; Handan

Balkara) İstanbul, Varlık Yayınları.

ILGIN, B. (2010), Örgütsel Vatandaşlık Davranışlarının Oluşmasında Sosyal

Kaytarma İlişkisinde, Duygusal Zekâ ve Lider Üye Etkileşiminin Rolü, Yayınlanmış

Doktora Tezi, Hacettepe Üniversitesi, Sosyal Bilimler Enstitüsü, 2010.

HACKMAN, J. Richard \& OLDHAM, G. R. (1980) Work redesign, Massachusetts,

Addison-Wesley Publishing Company, p.78-80

İSLAMOĞLU, H. (2003). Bilimsel araştırma yöntemleri. İstanbul, Beta Basım.

KARAGÜL, V. (2018) Osmanlı-Türk Modernleşme Sürecinde Mülki İdare ve Müki İdare Amirliği, İstanbul, Kesit Yayınları.

KARATEPE, O. M. \& OLUGBADE, O. A. (2009), The effects of job and personal resources on hotel employees' work engagement. International Journal of Hospitality Management, Cilt: 28, 504-512.

KESER, A. (2018), «İște Mutluluk Araştırması.» Paradoks Ekonomi, Sosyoloji ve

Politika Dergisi, Cilt: 14.1, 43-57.

KÖSE, E. (2014). Scientific research models, In R. Kıncal, Scientific research methods (pp. 110-123). Ankara, Nobel Press.

MAYER, J. D. \& P. SALOVEY (1997), "What Is Emotional Intelligence”, In P.

Salovey, \& D. Sluyter, Emotional Development And Emotional Intelligence: Educational Implications (pp. 3-34). New York, Basicbooks, Inc.

MAYER, J. D., DIPAOLO \& P. SALOVEY (1990), "Perceiving Affective Content in

Ambiguous Visual Stimuli: A Component of Emotional Intelligence", Journal of Personality Assessment, Cilt: 54: 772-781.

MEB Tamer Özyurt İlkokulu, 12.10.2018 Tarih ve 345 sayılı yazısı. «Yabancı uyruklu öğrenci sayıları.» Resmi yazı, 23.09.2018. 
NAZLI, M. (2015), Hizmet Sektöründe Kurumsal Yönetimin İște Mutluluk Üzerine Etkisi, Yayınlanmış Doktora Tezi, Yaşar Üniversitesi, Sosyal Bilimler Enstitüsü, İzmir.

NEÇARE, E. (2017) “Duygusal Zekâ ve Etik Karar Verme İlişkisi: İnsan Kynakları Alanında Bir Araștırma” Yayınlanmış Yüksek Lisans Tezi, Yıldız Teknik Üniversitesi Sosyal Bilimler Enstitüsü, İstanbul.

SALOVEY, P. \& MAYER, J.D. (1990). Emotional intelligence. Imagination, Cognition, and Personality, Cilt: 9, 185-211.

SÖZER, B. Ö. (11 Ocak 2015). Arbejdsglaede ne demek biliyor musunuz?

Hürriyet. (Erişim Tarihi: 12 Ocak 2015), http://www.hurriyet.com.tr/ik/27931185.asp

SUDAK, M. K. (2011), Kişilik tipleri, duygusal Zekâ, örgütsel vatandaşlık davranışı ilişkisi üzerine bir araştırma, Yayımlanmış Doktora Tezi, Gebze Yükek Teknoloji Enstitüsü, Gebze.

ŞAHİN, S., AYDOĞDU, B., \& YOLDAȘ, C., (2011) Duygusal Zekâ ve İș Doyumu Arasındaki İlişki: Eğitim Müfettişleri Üzerinde Bir Araștırma, İlköğretim-Online Dergisi, 10(3), 974-990, 2011, s. 986.

\section{Summary}

In this study, it was investigated whether there is a relationship between emotional intelligence levels of school administrators and workplace happiness levels. The study was conducted on primary, secondary and high school administrators on the European side of Istanbul. Firstly, a general literature review has been made and global sources have been examined. The questionnaires and scales which were used to measure the variables discussed in the study and which were thought to be best expressed were clarified. The collected data were converted into statistical data through SPSS program. Then, the available data were interpreted and discussed in the light of the literature. According to the results of the research, significant and positive relationships were found between the emotional intelligence sub-dimensions of school administrators and workplace happiness sub-dimensions. It was found that the higher the level of emotional intelligence, the higher the happiness of the workplace, and the higher the level of emotional intelligence of the school administrators who have high workplace happiness.

Although cognitive-logical intelligence (IQ) is the most important factor that plays a role in success, the most effective guide that will lead it to success is the capacity of emotional intelligence (EQ). We have no influence on the cognitive intelligence level of our children. However, by increasing the level of emotional intelligence, we have an influence in the process of making the individual a hardworking, honest and successful member of society. It is possible for us to use this power effectively and efficiently, by adding subjects that will increase emotional intelligence to the curriculum, and by educating teachers and education administrators to close this education gap and to raise awareness. Accumulated chronic problems in the field of education in Turkey scale influx of refugees in recent years and the extra hassle that you install it to the school, not giving grants to schools, especially in metropolitan problems such as the lack of schools in the suburbs, manager imposes a duty superhuman. In addition to being cognitively intelligent, the school manager who can handle this burden needs to have good emotional intelligence competencies and to act as the main actors in creating a positive working environment for such diverse stakeholders, and to have high levels of workplace happiness. It is obvious that school administrators perform a very important task because of the importance of the stakeholders and actors they address and the sensitivity of their work to the society. It is very important for the people who perform this important task to have a superior standard of emotional intelligence. However, being happy in their business is also vital for the moral motivation and happiness of the institution 
and their stakeholders. The decision of the manager whose emotional intelligence is very strong will be passed through the ethical values filter and the emotional intelligence ability will be beneficial. Training programs should be developed to increase the emotional intelligence levels of school administrators. With the same variables of the research, it is possible to work on stakeholders at all levels of education.

The characteristics of the universe in which our study is applied may be different. Schools differ according to their environment. Therefore, Turkey can not be generalized to all school administrators. This is the limitation of our study. This study can be applied especially to the managers in provincial and district national education directorates which are responsible for making important decisions in the management services class. Scales to measure emotional intelligence levels should be developed especially for school administrators, teacher and all staff in educational environments, and evaluation studies should be conducted on case studies. On the other hand, more social chameleons can be caused by excessive mastery in the use of emotions and the ability to manage emotions; researches suggest that an emotional intelligence ability without ethical values is not good. It can be argued that this is a subject that needs attention in the studies to be carried out. Executive trainings can be programmed and scales can be developed for the concept of 'social chameleon'. 